\title{
First colour-patterned strophomenide brachiopod from the earliest Devonian of Podolia, Ukraine
}

\author{
Andrzej Baliński \\ Acta Palaeontologica Polonica 55 (4), 2010: 695-700 doi: http://dx.doi.org/10.4202/app.2010.0066
}

Retained colour pattern on the shells of Plectodonta sp. from the earliest Devonian of Podolia (Ukraine) is the first finding for strophomenide brachiopods and the oldest among articulate brachiopods. The colour pattern in Plectodonta sp. is composed of small, round, brownish spots scattered rather irregularly on the ventral valve only. This may suggest that the described pattern probably performed a protective function through disruptive camouflage against visual systems of potential predators. The occurrence of the colour pattern in Plectodonta sp. exclusively on the ventral valve strongly suggests that these brachiopods lived with the patterned (and convex) ventral valve upwards and the patternless concave dorsal valve facing to the underlying substrate. It thus contradicts a general assumption that concavo-convex brachiopods lived with their convex valves resting on the sediment.

Key words: Brachiopoda, Strophomenida, colour pattern, Devonian, Podolia.

Andrzej Baliński [balinski@twarda.pan.pl], Instytut Paleobiologii PAN, ul. Twarda 51/55, PL-00-818 Warszawa, Poland.

This is an open-access article distributed under the terms of the Creative Commons Attribution License (for details please see creativecommons.org), which permits unrestricted use, distribution, and reproduction in any medium, provided the original author and source are credited. 